\title{
Effect of Soft Drink, Electronic Media Exposure, Family Income, Pocket Money, and Nutritional Status, on Age at Menarche Among Adolescents in Surakarta
}

\author{
Mirzawati Latifah'), Bhisma Murti'), Yulia Lanti Retno Dewi²) \\ 1)Masters Program in Public Health, Sebelas Maret University \\ ${ }^{2)}$ Department of Nutrition, Faculty of Medicine, Sebelas Maret University
}

\begin{abstract}
Background: Age at menarche has become earlier for the last 100 years. This situation poses worrying problem as it may be lead to an increased risk of premarital sex, teenage pregnancy, mental unpreparedness, and increased risk of malignant diseases such as ovarian cancer and breast cancer. This study aimed to determine the effect of soft drink, electronic media exposure, family income, pocket money, and nutritional status, on age at menarche among adolescents in Surakarta. Subjects and Methods: This was an analytic observational study with cross-sectional design. The study was conducted in Surakarta, Central Java, from February to March, 2017. A sample of 100 female adolescents was selected by simple random sampling from several Junior High Schools in Surakarta. The exogenous variables were nutritional status, family income, and electronic media exposure. The endogenous variables were age at menarche, soft drink consumption, and pocket money. The data were collected by a set of questionnaire, and analyzed by path analysis.

Results: Age at menarche was affected by electronic media exposure $(b=-0.65 ; \mathrm{SE}=0.25 ; \mathrm{p}=$ $0.010)$, pocket money $(b=-7.48 ; \mathrm{SE}=1.52, \mathrm{p}<0.001)$, soft drink $(b=-3.43 ; \mathrm{SE}=1.11 ; \mathrm{p}=0.002)$, and nutritional status $(b=-1.31 ; \mathrm{SE}=-0.59 ; \mathrm{p}=0.025)$. Nutritional status was affected by family income $(\mathrm{b}<0.01, \mathrm{SE}<0.01, \mathrm{p}=0.323)$ and pocket money $(\mathrm{b}=0.24 ; \mathrm{SE}=0.29 ; \mathrm{p}=0.401)$. Electronic media exposure was affected by pocket money $(b=0.69 ; \mathrm{SE}=0.58 ; \mathrm{p}=0.234)$. Soft drink was affected by pocket money $(b=0.23 ; \mathrm{SE}=0.13 ; \mathrm{p}=0.074)$. Pocket money was affected by family income $(b<0.01$; $\mathrm{SE}<0.01 ; \mathrm{p}<0.001)$.

Conclusion: Age at menarche is directly affected by electronic media exposure, pocket money, soft drink, and nutritional status. Age at menarche is indirectly affected by family income, pocket money, and electronic media exposure.
\end{abstract}

Keywords: path analysis, menarche, soft drink, reproduction health

\section{Correspondence:}

Mirzawati Latifah. Masters Program in Public Health, Sebelas Maret University, Jl. Ir. Sutami 36 A, Surakarta 57126, Central Java. Email: Mirzawati.Latifah@gmail.com. Mobile: 082218490968.

\section{BACKGROUND}

The rapid changes in menarche in the world are observed from adolescence who is influenced by many contributing factors. The declining in menarche age has been observed for the last 100 years and it created a very concerning problems in teenagers. Until now, the researchers are still undergoing researches on the reason of the menarche age declining in the world (Al-Agha, 2014).

The steps in adolescence are divided into two, i,e.: early adolescence and late adolescent. Early adolescence started around 10-14 years old and late adolescence started around 15-19 years old (UNICEF, 2011). While from Indonesian Ministry of Health (2014) concludes that adolescence is around 10-19 years and unmarried. 
Female adolescent facing menarche at a young age will face differences in their later stage in life compared to teenagers experiencing normal puberty period because this is in related to the increasing risk of pre-marital sex and teen pregnancy, low mental in teenagers, heart disease, and other malignant diseases such as ovarian cancer, breast cancer (Kelly et al., 2016).

Female adolescent facing earlier menarche compared their peers could cause early menopause and thus increasing their risk of breast cancer. Breast cancer is still one of the most terrifying disease for women today (Lancet oncol, 2012). Early age menarche also increases the risk of early diabetes melitus which happened 3040 and 40-50 years old (Lim et al., 2014).

The most dynamic event in the western culture is that the average menarche in teenagers happens at around $\mathbf{1 2 . 5}$ years of age (Irianto, 2014). The menarche age in Europe is facing drastic declining from 17 years of age to 13 years of age from mid 19th century to mid 2oth century. Early menarche in the teenagers in Europe could be observed in Greece and Finland where the average menarche age is 12.3 and 13.3 years of age (Steingraber, 2015 in Ahmed et al., 2016). The declining of menarche age in female adolescent in Brazil is around 3.6 months per decade (Castilho et al., 2012).

Based on the result of Riset Kesehatan Dasar in (2010) the beginning of early menarche lessen at 9 years of age, a small number of children experienced menarche $<0.5 \%$ at age 6-8 years old and experiencing menarche slower at the age 20 years old. As many as 5.2\% of teenagers in 17 provinces in Indonesia experienced menarche below 12 years of age. Based on the declining number of menarche, Indonesia sits on the $15^{\text {th }}$ seat of 67 countries in the declining menarche age with 0.15 year per decade.
According to data by Riskesdas (2013) the population proportion $\geq 10$ years old with risky food per Provinces. The consumption of sweet drinks, food $\geq 1$ time/ day nationally is (53.1\%). Jawa Tengah province consumption pattern of risky drinks is $(20.2 \%)$ and caffeine other than coffees is (4.4\%). There are 5 provinces with the highest food and drinks consumption: Kalimantan Selatan (70.4\%), Yogyakarta (69.2\%), Kalimantan Tengah (67.6\%), Sumatera Selatan (63.3\%) and Sumatera Utara (62.5\%).

Based on a preliminary study in several junior high schools in Surakarta, from 28 students of the 7 th grade, there were 15 students who experienced menarche at the age 12 years old and 13 students experienced menarche at age 11 years old.

\section{SUBJECTS AND METHOD}

\section{Design of the Study}

The design of the study used in this research was analytic observational with cross-sectional approach. Data collection was done in SMPN 3, SMPN 4, SMPN 5, Surakarta on Febuary-March 2017.

\section{Population and Sample}

The target population in the study was all female adolescent of the 7 th grade in Surakarta. There were as many as 100 students as the sample. Sampling was conducted by using purposive sampling in Kecamatan Banjarsari, Surakarta. Simple random sampling used to select several schools, and proportional random sampling used to collect the subject of the study.

\section{Research Variables}

The variables in this study consisted of five variable which consisted of exogenous and endogenous variables. The exogenous variables in this study were family income, nutritional status, and electronic media exposure. Whereas the endogenous varia- 
Journal of Maternal and Child Health (2017), 2(1): 54-63

https://doi.org/10.26911/thejmch.2017.02.01.06

bles were pocket money, soft drink, and menarche age.

\section{Operational Definition of the Variables}

The operational definition of these variables comprised of pocket money, electronic media exposure, family income, nutritional status, and soft drink consumption.

Pocket money was defined as money coming from the parents to be spent on necessities such as food or soft drink. The definition of soft drink consumption was the amount of soft drinks consumed by the subject for the last 7 days, both carbonated and non carbonated drinks.

Family income was defined as the monthly income earned by the parents: father or mother; to fulfill the family's needs. Electronic media exposure was defined as the adolescent experience in watching adult contents about sexuality and reproductive health as obtained from the radio, television, films, and online media or the internet. Adult contents such as soap operas or television films with sensual scenes such as rapes, lips or forehead kissing, or sexual intercourse.

Nutritional status defined as the end result of the balance of consumed nutrition and its utilization measured by their body mass index (BMI) by comparing their weight $(\mathrm{kg})$ divided by height (m) squared and grouped as per their age.

\section{Instrument of the Study}

The data was collected using questionnaire. The questionnaire used underwent validity and reliability tests before being used to collect data. Based on the reliability test result that was done by measuring the electronic media exposure variable, it was gathered that the correlation item point total 0.69 and Alpha Cronbach 0.76. All of the points of the questionnaire was confirmed reliable.

\section{Data Analysis}

The analysis used was quantitative data done by univariate to show patient data characteristic and descriptive variable study, bivariat analysis to analyze the effect of the exogenous variables towards the endogenous variables using Chi-Square testing, and path analysis. The analysis of the effect of endogenous variables through in-between variables and to understand the direct and indirect effect of the exogenous and the endogenous.

\begin{tabular}{l}
\hline RESULT \\
Table 1 showed that from 100 subjects of \\
the study, mostly aged 12 years old as many \\
as 49 subjects (49\%) and 13 years old as \\
many as 49 subjects ( $49 \%$ ) and only 2 \\
subjects aged 14 years old (2\%). 48 subjects' \\
fathers worked as employees for private \\
companies ( $48 \%)$. 2 subjects' fathers \\
worked as a labourer. Whereas $51 \%$ of the \\
subjects' mothers worked as housewives. \\
$4 \%$ of the subjects' mothers worked as \\
labourer.
\end{tabular}

The result of continuous data of descriptive statistic in the form of soft drink consumption, electronic media exposure, nutritional status, pocket money, and family income could be seen on Table 2.

Table 2 showed that each variable had very small differences in the data. Mean showed the average scores, while standard deviation (SD) showed how far the differences existed. Small SD scores is an indication that the data is representative.

The higher the family income, the earlier the menarche age. The more the pocket money, the faster the menarche starts. The higher the exposure of the electronic media, the quicker the menarche. The higher their soft drink consumption, the faster the menarche. On Table 3 it was explained that the higher the nutritional 
Latifah et al./ Effect of Soft Drink, Electronic Media Exposure, Family Income,

status of the adolescent, the faster they

would have menarche.

Table 1. Subject characteristic of the study

\begin{tabular}{lcc}
\hline \multicolumn{1}{c}{ Variables } & n & \% \\
\hline Age & & \\
12 years old & 49 & 49.0 \\
13 years old & 49 & 49.0 \\
14 years old & 2 & 2.0 \\
Father's occupation & & \\
Civil Servant & 18 & 18.0 \\
Employees & 48 & 48.0 \\
Entrepreneur / trader & 19 & 19.0 \\
labourer & 2 & 2.0 \\
Jobless & 13 & 13.0 \\
Pekerjaan Ibu & & \\
Civil Servant & 9 & 9.0 \\
Employees & 16 & 16.0 \\
Entrepreneur / trader & 20 & 20.0 \\
labourer & 4 & 4.0 \\
Jobless/Housewife & 51 & 51.0 \\
\hline
\end{tabular}

Tabel 2. Description of research variables

\begin{tabular}{lccccc}
\hline \multicolumn{1}{c}{ Variables } & n & Mean & SD & Min & Max \\
\hline Adolescent Nutritional status & 100 & 0.56 & 1.29 & -2.94 & 2.74 \\
Electronic media exposure & 100 & 13.86 & 2.96 & 9 & 25 \\
Soft drink consumption & 100 & 2.60 & 0.68 & 1 & 3 \\
Family income & 100 & 344.6 & 152.8 & 100 & 800 \\
Pocket money & 100 & 1.15 & 0.50 & 0.5 & 2.5 \\
Menarche ageUsia menarke & 100 & 134.0 & 9.46 & 118 & 152 \\
\hline
\end{tabular}

On Image 1, it showed the structural model after estimation using IBM SPSS AMOS 22. The indicators showed the congruence of path analysis model as showed on table 4 and also the existence of goodness of fit measure obtained fit index result $\mathrm{CMIN}$ as many as 8.47 with $\mathrm{p}=0.205$

Table 3. Pearson product moment correlation test among nutritional status, family income, adolescent pocket money, electronic media exposure, soft drink consumption and menarche age.

\begin{tabular}{lcc}
\hline \multicolumn{1}{c}{ Variables } & r & p \\
\hline Nutrional Status (BMIfor Age) & -0.23 & 0.018 \\
Family income (IDR/month) & -0.42 & $<0.001$ \\
Adolescent pocket money (IDR/day) & -0.50 & $<0.001$ \\
Electronic media exposure (score) & -0.28 & 0.006 \\
Soft drink consumption (times/week) & -0.32 & 0.001 \\
\hline
\end{tabular}

On table 4 , it could be seen that the menarche age was influenced by electronic media exposure, pocket money, soft drink, and nutritional status (BMI/Age). Every
$>$ 0.05; NFI (Normed Fot Index) $=0.91$ $>0.90$; CFI (Comparative fit index) $=0.97$ $>0.90$; RMSEA (Root Mean Square eror of Approximation $)=0.06<0.08$ meaning that the empirical model met the criteria set and confirmed meeting the empirical data. one unit increase in the exposure of the electronic media, it would lower the menarche age by -0.65 unit $(b=-0.65 ; \mathrm{SE}=$ $0.25 ; \mathrm{p}=0.010)$. Every one unit increase in 
Journal of Maternal and Child Health (2017), 2(1): 54-63

https://doi.org/10.26911/thejmch.2017.02.01.06

the pocket money, it would lower the

$1.52 ; \mathrm{p}<0.001)$.

menarche age by -7.48 unit $(b=-7.48 ; \mathrm{SE}=$

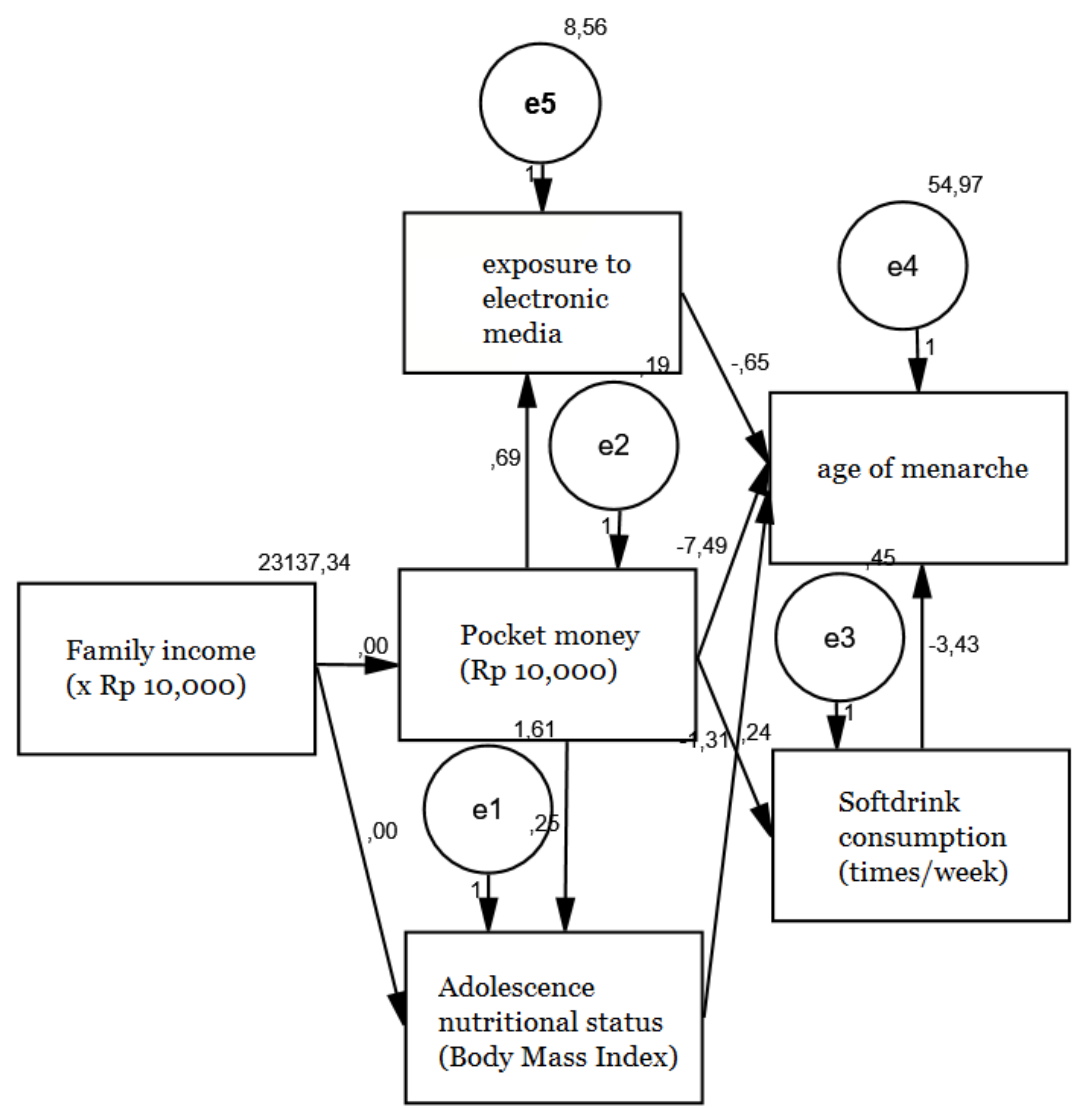

Image 1. Path Analysis Structural Model

Every unit increase in soft drink consumption, it would lower the menarche by -3.43 unit $(b=-3.43, \mathrm{SE}=1.11, \mathrm{p}=0.002)$. Every one unit increase in the nutritional status, it would lower the menarche age by -1.31 unit $(b=-1.31, \mathrm{SE}=-0.59, \mathrm{p}=0.025)$.

Tabel 4. Path analysis result on the factors affecting adolescent menarche age

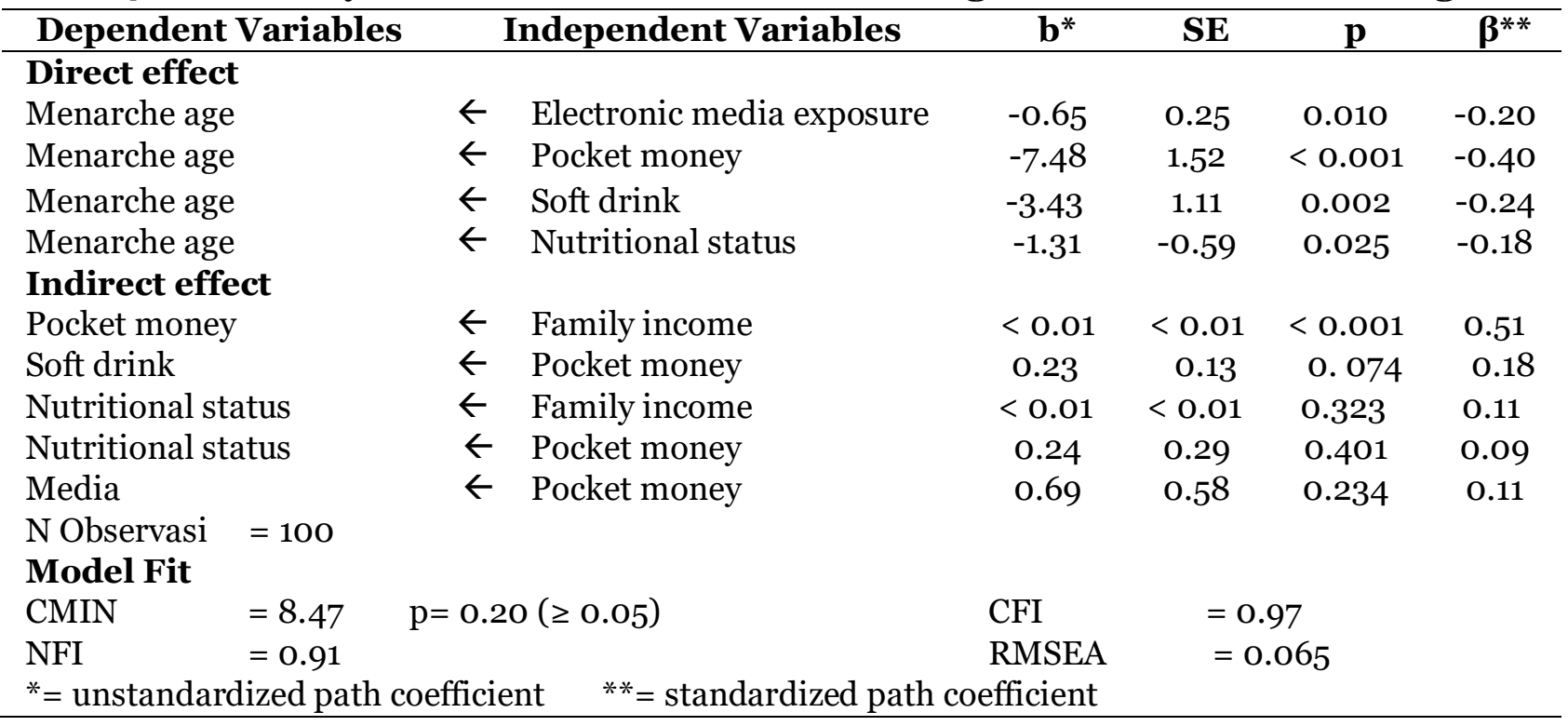


Nutritional status was affected by the family income and their pocket money. Every one unit increase in the family income, it would increase the nutritional status by 0.01 unit $(\mathrm{b}=0.01 ; \mathrm{SE}<0.01 ; \mathrm{p}=$ 0.323). Every one unit increase in the pocket money, it would increase the nutritional status by 0.24 unit $(b=0.24 ; \mathrm{SE}=$ 0.29; $\mathrm{p}=0.401$ ).

Pocket money was affected by family income. Every one unit increase in the family income, it would increase the pocket money by 0.01 unit $(\mathrm{b}=0.01$; $\mathrm{SE}<0.01$; $\mathrm{p}<0.001$ ).

Soft drinks consumption was influenced by pocket money. Every one unit increase in the pocket money, there would also an increase in soft drink consumption by 0.23 unit $(b=0.23, \mathrm{SE}=0.13, \mathrm{p}=0.074)$.

Electronic media exposure was influence by their pocket money. Every one unit increase in the pocket money, the exposure of electronic media would also increase by 0.69 unit $(b=0.69 ;$ SE 0.58; $p=0.234)$.

\section{DISCUSSION}

\section{The influence of family income towards menarche age}

There is a positive and statistically significant relationship between the family income through their pocket money and adolescent menarche age. Monthly family income or revenue has become one of the deciding factors in the family life (Khalid et al., 2015) keeping in mind every basic need has become more expensive and increasing. The family income has become something very important to support the family economy.

Parents with bigger income could easily fulfill the family's needs, whereas parents with less income would have the tendency to find it difficult to make ends meet. The level of income influences the living condition of each family. Parents with more income could give more pocket money to the children. Thus, it could be said that family income influences how much the pocket money a child gets. According to Radha and Chellappan (2015) adolescent growing in high or well economy would have faster menarche than children coming from families with low economy.

This study is in accordance with the findings by Yadaf and Choubey (2017) that there is a relation between family's social economy with the menarche age. The amount of family members and family income has become one of the factors affecting adolescent menarche age. The family income is also influenced by the number of family members and the amount of pocket money each child gets, high income with small number of family members would influence how much the pocket money a child gets. Children with more pocket money would easily purchase snacks or soft drinks. The higher the family income, the number of a child's pocket money would also increase and thus influencing its soft drinks consumption.

\section{The influence of pocket money towards adolescent menarche age}

There is a direct negative and statistically significant relation between pocket money and menarche age and indirect positive relation between pocket money through soft drinks towards adolescent menarche age. According to Aini (2013) adolescent with pocket money $\geq \operatorname{Rp} 10,000$ per day has more power to purchase more snacks and drinks than adolescent with $<\mathrm{Rp} 10,000$ pocket money. It means that with more pocket money, the adolescent could purchase whatever they like and they prefer to purchase modern snacks or drinks hoping that their peers would accept them.

Pocket money is the money given to the adolescent from their parents to fulfill their needs. This money is the result of 
family income or earnings given to the child for their daily, weekly, or monthly needs (Koenjaraningrat, 2000 in Dilapanga, 2008). The pocket money given could be used to fulfill the adolescent's needs such as to purchase snacks or drinks in terms of soft drinks. The pocket money could also become the deciding factor in buying the soft drinks. And vice versa, adolescent less pocket money would be more frugal in spending their pocket money.

The findings in the study is in accordance with the study done by Al-Agha et al., (2014) that shows that there is a relation between soft drinks consumption and adolescent menarche age. The amount of pocket money influences the adolescent consumptive pattern. Soft drinks in this modern era is not something difficult to get. Soft drinks are a type of drinks adolescent would choose to quench their thirst.

The sweet taste and assorted flavors attracts the adolescent to choose soft drinks as their way to spend their pocket money. Al-Agha (2014) states that junk food and soft drinks consumption could affect the growth of pubic hair in the female genital. Thus, the maturity of the reproductive organs would trigger faster menstrual period.

\section{The influence of soft drinks towards adolescent menarche age}

There is a negative and significant relation between soft drinks consumption and adolescent menarche age. According to Carwile et al., (2015) there is a direct effect to adolescent that consumes soft drink in high frequency. The high amount of added sugar intake in the soft drinks would increase insulin concentration. The direct effect of this added sugar could influence the hormonal function of the female reproductive organ. Insulin could affect the work of globulin and could influence the growth in protein production factor. Hence, it would then influence the working concentration of the sex hormones then causing a female adolescent to experience faster menarche.

Soft drink are divided into two kinds, namely carbonated and non carbonated drinks. Soft drinks usually contain sugar and caffeine thus making the content of soft drinks bad for health. Based on several studies, there are several problems related to excessive soft drinks consumption. Excessive soft drink consumption could trigger diabetes, overweight, obesity, and bones demineralization (NSW Centre for Public Health Nutrition, 2009). Soft drinks could also influence the reproductive health of women of reproductive age, like accelerating the age of menarche in adolescents.

The result of this study is in accordance to the study done by Mueller et al., (2015) and Carwile et al., (2015), that explains that there is a relation between soft drinks consumption and menarche age in adolescent. Adolescent consuming soft drink $\geq 1.5$ times/day from the age of 9 to 18.5 years old is $24 \%$ more potential to face early menarche than adolescent consuming soft drink <2 times/week. Excessive soft drink consumption does not stop at early menarche. The effect on health of adolescent having early menarch also contributes to bad women's health such as increasing the risk of heart diseases, type 2 diabetes, non-alcoholic fatty liver, and hormonrelated cancers like ovarian and breasts cancers.

\section{The influence of electronic media exposure towards adolescent menarche age}

There is negative relation between electronic media exposure and adolescent menarche age. There is positive relation between pocket money and electronic media exposure. Some factors that could influence the sexual behavior in adolescent namely 
physical growth, physical, learning process, science and technology, and sociocultural. The development of internet towards the gadgets and smartphones that used frequently by the adolescent in making social interaction (Romauli dan Vindari, 2011). The developing adolescent sexual behavior could accelerate the growth of the reproductive organs. Such behavior stimulated the female adolescent to experience early menarche.

The result of this study is in accordance to the study done by Wulandari et al., (2015) that explained the relation among mothers' menarche age (genetic), mass media exposure, lifestyle, nutrition with the menarche of the female students in SMPN 31 Semarang. Electronic media is the axis of the rapid development of technological sophistication in today's modern times. There are a lot of positive and negative things comes up with the development of the technology. Adolescent have the tendency to have high curiosity thus sometimes with the lack of supervision from the parents makes the adolescent pushed to get in on something negative, such as viewing adult content or listening to adult conversations through the electronic media.

Adolescent with higher exposure to the electronic media with adult contents will face maturity in the mind and thus it triggers the maturity of the reproductive organs. The maturity of reproductive organs could stimulate sex hormons and causing early menarche faster than their peers with lower exposure of the electronic media with adult contents.

\section{The influence of nutritional status towards the menarche age}

There is direct negative and statistically significant between the nutritional status and menarche age in adolescent. Taller and heavier adolescent would experience faster menarche. Meaning that the better the nutrition one has, the faster the menarche. Several experts mention that the high fat in adolescent causing the adolescent to experience faster menarche compared to their peers (Karapanaou dan Papaimitriou, 2010).

Today's adolescent grow with the high and modern technological facility. Thus makes it easier for the adolescent to access pornographic services. Soap opera and films in television filled with sensual and violent scenes trigger the adolescent to copy the behavior showed on the soap opera or films. Rape scenes towards women, lips or forehead kissing, intimate scenes where husband and wife is visualized by having a man and woman sharing the same bed under the blanket covering the chest for actress and covering the hips for the actor are examples of sensual scenes on mass media (Suryati and Lestari, 2011).

The result of this study is in accordance to the study done by Al-Awadhi et al., (2013) that stated that there is a relation between nutritional status and menarche age. The high BMI of a female adolescent in pre puberty could increase the supply production of estrogen inside their body. The high estrogen increase intensify the fat deposits in the adipose tissue. The high amount of estrogen inside their body caused the female adolescent to face earlier menarche compared to their peers.

The result of this study also showed positive between family income and the adolescent nutritional status. There is a positive relation between the pocket money and the adolescent nutritional status.

The nutritional status is a measurement of the success in the fulfilling the nutrition used as health status or balance between the needs and the food intake. According to Irianto (2014), the nutrition is an organism process that uses food then 
consumed normally through absorption, transportation, storage, metabolism, and extraction of unused substance to maintain life, growth, and normal functions of the organs and then resulting in energy.

According to Yadaf and Choubey (2017), they stated that there is a relation between social economy status and menarche in adolescent. High family income will affect the nutritional status of the children. The better the family income, the better the children's nutritional status. This condition is due to the higher the family income, thus it becomes easier for them to fulfill the needs, and vice versa. Families with low income will find it difficult to fulfill their needs and the condition will influence the nutritional status in adolescent. Family income will affect the amount of pocket money.

Based on the study by Raje (2017) that stated that there is a relation between nutritional status towards adolescent menarche age. The menarche age could be influenced by the energy and fat intake, the more the pocket money, the easier for the adolescent to purchase junk food and consume soft drinks, while adolescent with low nutritional status also have low health status. This causing the adolescent to face late menarche age.

\section{REFERENCES}

Ahmed S, Waheed M, Ahmad F, Danish H (2016). Factors contributing to early menarche in school girls. J Pak Med Assoc 66(5).

Aini NS (2013). Faktor Risiko yang Berhubungan dengan Kejadian Gizi Lebih pada Remaja di Perkotaan. Unnes Journal of Public Health 2(1).

Al-Agha A, Saeedi R, Tatwany B (2014). Correlation between Nutrition and Early Puberty in Girls Living in
Jeddah Saudi Arabia. Women's Health Care 4(3).

Al-Awadhi N, Al-Kandari N, Al-Hasan T, Ali S, Al-Taiar A (2013). Age at Menarche and its relationship to body mass index among adolescent girls in Kuwait. Biomed Central 13:29.

Castilho SD, Pinheiro CD, Bento CA, Barros-Filho AA, Cocetti M (2012). Secular trends in age at menarche in relation to body mass index. Arq Bras Endocrinol Metab. 56: 195-200.

Carwile JL, Wilett WC, Spiegelman D, Hertzmark E, Rich-Edwards J, Frazier AL, Michels KB (2015). Sugar sweetened beverage consumption and age at menarche in prospective study of US girls. Human Reproduction 30(3): 675-683.

Dilapanga A (2008). Faktor-Faktor yang Berhubungan dengan Perilaku Konsumsi Soft Drinks pada Siswa SMP Negeri 1 Ciputat Tahun 2008. Jakarta: Universitas Islam Negeri Syarif Hidayatullah.

Irianto K (2014). Gizi Seimbang dalam Kesehatan Reproduksi. Bandung: Alfabeta Bandung.

Karapanou O, Papadimitriou A (2010). Determinants of menarche. Reproductive Biology and Endocrinology 8(115).

Khalid H, Khawar K, Fawad M, Farhat M, Imran M, Shahnawaz M, Shahid M, Yousaf P, Saleem Q, Ahmed S, Sarwar R, Ali KH, Humayun A (2015). Age of Menarche in Relation to Sosioeconomic Status BMI, physical Activity and Stress Among High School Girls. Proceeding S.Z.P.G.M.I 29: 35-40.

Kelly Y, Zilanawala A, Sacker A, Hiatt R, Vinner R (2016). Early Puberty in 11 Year old Girls: Millennium Cohort Study Findings. Arc Dis Child o: 1-6. 
Lancet Oncologi (2012). Menarche, menopause, and Breast Cancer Risk: Individual Participant meta-analysis, including 118964 Women With Breast Cancer From 117 Epidemiologi Studies. https://www.ncbi.nlm.nih.govpmc-articles-PMC3488186/. Diakses pada tanggal 15 Desember 2016.

Lim JS, Lee HS, Kim EY, Yi KH, Hwang JS (2014). Early Menarche Increase the Risk of Type 2 Diabetes in Young and Middle-aged Korean Women. Diabetes Medicine, 4: 521-5.

Mueller N, Jacobs DR, Maclehose FR, Demerath E, Kelly PS, Dreyfus J, Pereira AP (2015). Consumption of Caffeinated and Artificially Swetened Soft Drinks is Assocoated With Risk of Early Menarche. American Society for Nutrition. 102: 648-54.

NSW Centre for Public Health Nutrition (2009). Soft Drinks, Weight Status and Health a Review. The University of Sidney.

Radha SS, Chellappan (2015). Age at Menarche and its Relation With Nutritional ans Sosioeconomic Status-A study Among Adolescent School Girls. International Journal of Medical Science and Public Health 4(6).
Raje L (2017). Age at Menarche Diet and Phsysical Activity. International food and Nutritional Science 6(1).

Riset Kesehatan Dasar (2010) Laporan Hasil Riset Kesehatan Dasar (RISKESDAS) Nasional. Jakarta: Badan Penelitian dan Pengembangan Kesehatan Kementerian Kesehatan RI.

Riskesdas (2013). Riset Kesehatan Dasar. http://www.depkes.go.id/resourcesdownload-general-Hasil-2oRiskesdas\%202013.pdf. Diakses tanggal 24 November 2016.

Romauli S, Vindari VA (2011). Kesehatan Reproduksi. Yogyakarta: 2011.

Suryati A, Lestari T (2011). Pengalaman dan pemahaman remaja usia awal (preteen) tentang seksualitas di Bekasi Jawa Barat. Jurnal Kesehatan 2(2).

Yadaf R, Choubey J (2017). Effect of Socioeconomic Status on the Onset of Menarche. Indian J.Sci.Res. 13 (2).

Wulandari P, Aini D, Astuti S (2015). Faktor-faktor yang berhubungan dengan Kejadian Menarche Siswi di SMPN 31 Semarang. Jurnal Keperawatan, 6(2). 